\title{
Modelling Seed System Networks in Mali to Improve Farmers Seed Supply
}

\author{
Harouna Coulibaly ${ }^{1}$, Didier Bazile ${ }^{2} \&$ Amadou Sidibé ${ }^{3}$ \\ ${ }^{1}$ Laboratoire Sol-Eau-Plante, Institut d'Economie Rurale, Bamako, Mali \\ ${ }^{2}$ CIRAD, UPR GREEN, TA C-47/F, Campus International de Baillarguet, F-34398 Montpellier, France \\ ${ }^{3}$ Chef de l'Unité des Ressources Génétiques, Institut d'Economie Rurale, Bamako, Mali \\ Correspondence: Dr. Didier Bazile, CIRAD, UPR GREEN, TA C-47/F, Campus International de Baillarguet, \\ F-34398 Montpellier, France. Tel: 33-467-593-853. E-mail: didier.bazile@cirad.fr
}

Received: August 6, 2014

Accepted: August 27, 2014 Online Published: August 29, 2014

doi:10.5539/sar.v3n4p18

URL: http://dx.doi.org/10.5539/sar.v3n4p18

\begin{abstract}
Food security remains a constant source of concern in Mali, where over $75 \%$ of the population derives their living from agriculture. Despite the huge theoretical need, the production and use of improved seeds remain very limited. Concurrently, genetic erosion and the disappearance of certain local varieties have been observed.

The dual need to preserve agricultural biodiversity as a factor of resilience for production systems while disseminating improved varieties as a means to increase production raises questions regarding what type or types of organization could best respond to these agricultural challenges. The farmer seed network in Mali is based on the self-production of pearl millet and sorghum seeds and operates through non-commercial, community-based exchanges. The formal seed sector distributes certified seeds through cooperatives, with cost-effectiveness the main priority. The joining of these two seed networks could allow agro-biodiversity to be considered in such a way that genetic diversity can be maintained.

The various pearl millet and sorghum seed exchange networks often are considered to be in opposition, with the formal network pitted against the informal one. By highlighting points where the two systems could come together, the proposed model allows a new perspective on seed flows and agro-biodiversity management. The global seed network that could emerge from this would, on one hand, remedy the failure of the state seed system inspired by a Western model in which seed production and distribution is disconnected from agricultural production, and, on the other, compensate for shortcomings in the traditional farmer seed system to increase productivity and sustainably manage farmer pearl millet and sorghum varieties while continuously introducing new genetic resources.
\end{abstract}

Keywords: Mali, pearl millet, sorghum, agrobiodiversity, seed networks, participatory research, modelling

\section{Introduction}

Pearl millet (Pennisetum glaucum) and sorghum (Sorghum bicolor) are the two main cereal crops cultivated in arid and semi-arid areas of Mali. The country is an important centre of secondary diversification of pearl millet and sorghum (Brush, 1995). The two crops constitute the staple food of the rural population and they continue to be widely consumed in urban areas, notably by disadvantaged groups.

There are numerous local varieties of pearl millet and sorghum which bear diverse vernacular names in each geographic area. The two species have very important phenotypic and genetic diversity within and between varieties, which enables them to adapt to different environments and withstand difficult climate conditions (Deu et al., 2010, 2014; Trouche et al., 1998; Vaksmann et al., 1996). Pearl millet and sorghum are cultivated in Mali on family farms in rain-fed systems that require few inputs, with notably a near total absence of chemical fertilizers and pesticides.

The local pearl millet and sorghum varieties grown by farmers have gradually evolved through the successive selections made by farmers to better respond to the production constraints of the different agricultural areas of the country (Sagnard et al., 2008). Thanks to their photoperiodic characteristic, pearl millet and sorghum can flexibly adapt to environmental changes in time and space (Soumaré et al., 2008). This characteristic renders it 
possible to easily adjust sowing dates to adapt to the variable start of the rainy season while remaining on schedule in relation to the end of the rains, which is always more regular, thereby allowing the grains to ripen correctly (Vaksmann et al., 2008). The average yield is estimated to be $800 \mathrm{~kg} / \mathrm{ha}$ nationally. These two cereals frequently are cultivated together in association with legumes such as cowpeas and peanuts. They often are sown in pure crops or mixed with varieties of the same species.

Since the 1960s, pearl millet and sorghum have been bred to obtain more productive varieties that can be grown in a wide range of environments. In this process, the photoperiodic character of local varieties was one of the first to be eliminated to enable them to be planted in all latitudes. The dissemination of these so called 'improved' varieties was made through official agencies under the Ministry of Agriculture, including the National Seed Service. However, this has not worked well because few farmers have adopted the improved varieties (they are used on about 10-15\% of farmland cultivated with these two species) (Matlon, 1985).

Despite the considerable efforts to establish a state seed system, the traditional seed system has held its own and continues to play a major role in testing and furnishing seeds (Brush 1991). The traditional system is furthermore the primary vector through which seeds circulate in rural areas, ensuring nearly $90 \%$ of seed exchanges between farmers (Bazile, 2006).

To remedy the failure of the state seed system and address the shortcomings of the traditional system, there are now several organizations through which improved seeds are produced and disseminated in Mali. However, the successful dissemination of improved varieties without a proactive approach to conserving agrobiodiversity threatens the genetic diversity of species and renders cultivated ecosystems more vulnerable (Almekinders et al., 1994; Almekinders \& Louwars, 2002; Altieri, 2004; Clawson, 1985; Cleveland et al., 1994; Wood \& Lenne, 1997).

Biodiversity produces countless goods and services (Naville, 2005; Caillon, 2005). Beyond its biological and economic potential, biodiversity also holds symbolic, social, cultural, and identity values (Barnaud, 2007). The conservation of agricultural biodiversity, which has been shown to be an essential component in the resilience of agricultural systems facing environmental, social, economic, and/or political disturbances, thus is critical (Altieri, 2002; Dudnik et al., 2001; Pham \& Van Hintum, 2000; Pretty et al., 2003; Trenbath, 1999).

This original study of the dissemination of improved varieties alongside the maintenance of pearl millet and sorghum biodiversity in Mali examines the seed systems likely to contribute to the resolution of the dilemma pitting plant improvement against local variety conservation (Ceccarelli, 1994; David et al., 2002; Fonteneau et al., 2005; Quang Tin et al., 2011; Sperling \& Loevinshon, 1993; Sperling et al., 2001; Weltzein et al., 2008). It is based on a comparative analysis of seed sub-systems (state and association-based) that are part of the overall farmer seed supply system (McGuire, 2005; Longley et al., 2002; Louwars \& Van Marrewijik, 1996; Tripp, 2001). These sub-systems, which function in the form of organized networks, are made up of different groups and individual actors working at different scales in the country (Lacy et al., 2006; Siart, 2008).

The study's main objective is to examine how interconnections between the seed networks of the global system impact the dissemination of improved seeds as well as the in situ conservation of traditional pearl millet and sorghum varieties. This allows the performance of sub-systems to be redefined in order to use their positive interactions to construct an alternative system.

\section{Materials and Methods}

Two administrative districts in Mali were chosen for the study, Ségou and Sikasso, based on the importance of pearl millet and sorghum farming, the presence of seed cooperatives run by the state seed system and the AOPP (Note 1) association-based seed network, and the availability of IER (Note 2)/CIRAD (Note 3) research results on farmer seed systems.

The choice of circles (an administrative level in Mali below the region) and study communes was made based on their proximity or distance from official certified seed multiplication centers disseminating improved varieties (Table 1). 
Table 1. Agro-climatic and administrative location of study villages

\begin{tabular}{|c|c|c|c|c|}
\hline Farm regions & Crop system & Circles & Communes & Villages \\
\hline Ségou & \multirow{4}{*}{$\begin{array}{l}\text { Cereals: (pearl millet, sorghum and flooded } \\
\text { and irrigated rice) with peanut }\end{array}$} & Ségou & Dioro & Babougou*, Dioro \\
\hline $\begin{array}{l}\text { Sahelian zone: } 400-700 \\
\mathrm{~mm} \text { of rain/year. }\end{array}$ & & & Sébougou & $\begin{array}{l}\text { Banankoroni*, } \\
\text { Sébougou }\end{array}$ \\
\hline Types of soils: clay, lime & & Tominian & Tominian & Kanian, Sokoro* \\
\hline and sand & & & Mandiakuy & Boumboro \\
\hline Sikasso & \multirow{3}{*}{$\begin{array}{l}\text { Cotton/cereals (maize, pearl millet, sorghum } \\
\text { and rice) with legumes }\end{array}$} & Koutiala & M'Pèssoba & M'Pèssoba (Sobala*), \\
\hline $\begin{array}{l}\text { Sudanian zone: } 800 \text { and } \\
1400 \mathrm{~mm} \text { of rain/year }\end{array}$ & & & & Danzana \\
\hline $\begin{array}{l}\text { Types of soils: clay, lime, } \\
\text { sand and gravel }\end{array}$ & & Sikasso & $\begin{array}{l}\text { Sincina } \\
\text { Fama }\end{array}$ & $\begin{array}{l}\text { Sincina, Kaniko } \\
\text { Fama, Siramana }\end{array}$ \\
\hline
\end{tabular}

Note: The villages marked with * are villages where seeds of different seed systems are multiplied.

At each of these administrative levels for our analysis, different surveys were conducted tailored to the actors involved at the level in question, and were complemented by observations of tasks, events, objects, and field visits.

The levels of intervention of the state, farmer, and association of farmer organizations seed systems do not always coincide with the administrative boundaries corresponding to national frontiers, regions, circles, rural communes and villages. To study the organization of these systems, it was necessary to consider the key characteristics of their structures at each of the different levels of spatial organization.

The research approach was based on survey tools (semi-structured interviews and questionnaires with closed questions) and ARDI (Actors/Resources/Dynamics/Interactions) conceptual modelling (Etienne et al., 2011) to simultaneously grasp the interactions between ecological and socio-economic dynamics and the interactions between different stakeholders (scientists, local actors, institutions, ...) involved in the management of pearl millet and sorghum seeds.

The survey work focused on a sample of four (4) seed cooperatives and analyzed in 2006, 2007, and 2011 the dissemination of seeds through the seed networks in thirteen (13) villages in the two most heavily agricultural administrative regions in Mali (Ségou and Sikasso).

A sub-sample consisting of 20 randomly selected farms were surveyed.

The questions were addressed to the farm head or his or her representative, who had sound knowledge of the farm-level management of pearl millet and sorghum varieties (origin, seed reproduction, seed quality, flux, etc.)

The results of the interviews and questionnaires were formalized in diagrams of actors-resources interactions where elements are linked by arrows indicating action verbs (logical "phrases") in accordance with ARDI methodology, applied in this case to an analysis of state and AOPP association-based seed systems.

The ARDI method is a good communication tool to raise awareness of interactions between seed network actors. It also is a good means to integrate (multi) disciplinary knowledge to bring to light a sustainable global system for the management of pearl millet and sorghum varieties by considering the diversity of representations of the same resource. It has the advantage of allowing sometimes contradictory objectives of diverse social groups to be taken into account (Etienne, 2006; Etienne, 2011; Daré et al., 2009). By allowing a better understanding of the functioning of seed networks and the complex relations between all of the actors, this conceptual modelling helps to formalize a discourse on a global seed system including interlocking seed systems (Farmer, State, and Farmer Organizations Association). These seed systems can be assimilated into these networks due to the social groups and institutions producing and exchanging particular types of seeds under particular standards and rules.

\section{Results: Diversity of Actors and of Seed Producers' Approaches to Supplying Farmers}

The pearl millet and sorghum seed system is a complex system. Its analysis is based on the idea that the sum of the system is greater than the contributions of each of the seed networks.

\subsection{Farmer Seed Production Network}

The farmer seed production network is based on the self-production of pearl millet and sorghum seeds. It operates within village communities through non-commercial exchanges based on a principle of solidarity.

The management of varieties by farmers consists of a dynamic process through which varieties, species, and 
associated practices are adjusted to local climate conditions. The farmers' practices and representations are inextricably linked to the agrarian society involved.

In the farmer seed system, on-farm production represents a farmer's principle seed supply source. Farmers mainly select seeds in the fields based on individual plants or particular panicles. At times, they may bring back seeds after trips within or outside their original farming region.

At the harvest, the farm head or his or her fieldwork deputy selects the seeds in the field using his or her own criteria: length of cycle, yield, resistance to diseases and pests, adaption to the soil, etc. (Bazile \& Soumare, 2004). These self-produced seeds are renewed at each harvest to be sown on the family farm the following year, although some may be conserved longer (up to 5 or 10 years in certain cases). Seed production knowledge and know-how are based on an annual, empirical learning process and this learning is shared within the community group. The experience accumulated is passed down from generation to generation and shared within the village farming territory to render agricultural production in the region stable and sustainable. This practice offers farmers the opportunity to select their own seeds according to their own criteria, and to prepare and conserve the quantities needed to satisfy their needs the following year by integrating the risks linked to variations in the climate and inter-annual production (Bazile et al., 2008). In general, a sufficient quantity of seeds is produced to allow three successive sowings to be carried out in case a crop fails to thrive.

The farmers' strategies for selection and production are based on environmental, socio-economic and demographic conditions, and integrate a set of appreciation criteria for local varieties related to the uses of the products obtained (Louwaars et al., 1996; Niangado, 2002). Consequently, the cereal varieties of a crop system are finely tuned to local conditions and farmer practices with relatively low (about $80 \mathrm{~kg} / \mathrm{year}$ ) but stable yields over the medium- term independent of the climate year, and this despite the ever present environmental hazards of this Sudano-Sahelian area.

Within the farmer seed system, social networks play a major role in the circulation of genetic resources and in the sharing of agricultural information that facilitates everyone's access to the diversity of seeds in a small farming region (Bocci \& Chable, 2008). The local seed systems are anchored in existing social structures (Figure 1). They develop and perpetuate themselves thanks to the social ties existing between related and unrelated families and work groups organized at the level of the village for particular agricultural activities (ex: harvest, threshing). These social networks promote and increase seed exchanges between different farmers and allow the continuous testing of local varieties in varied environmental and socio-technical contexts (de Boef et al., 2010). The relations of trust and kinship that rule within extended families, between neighbours, and even more widely, contribute to decisions regarding the choice of varieties thanks to the sharing of information about varieties that goes beyond the simple exchange of a biological resource, the seed. 


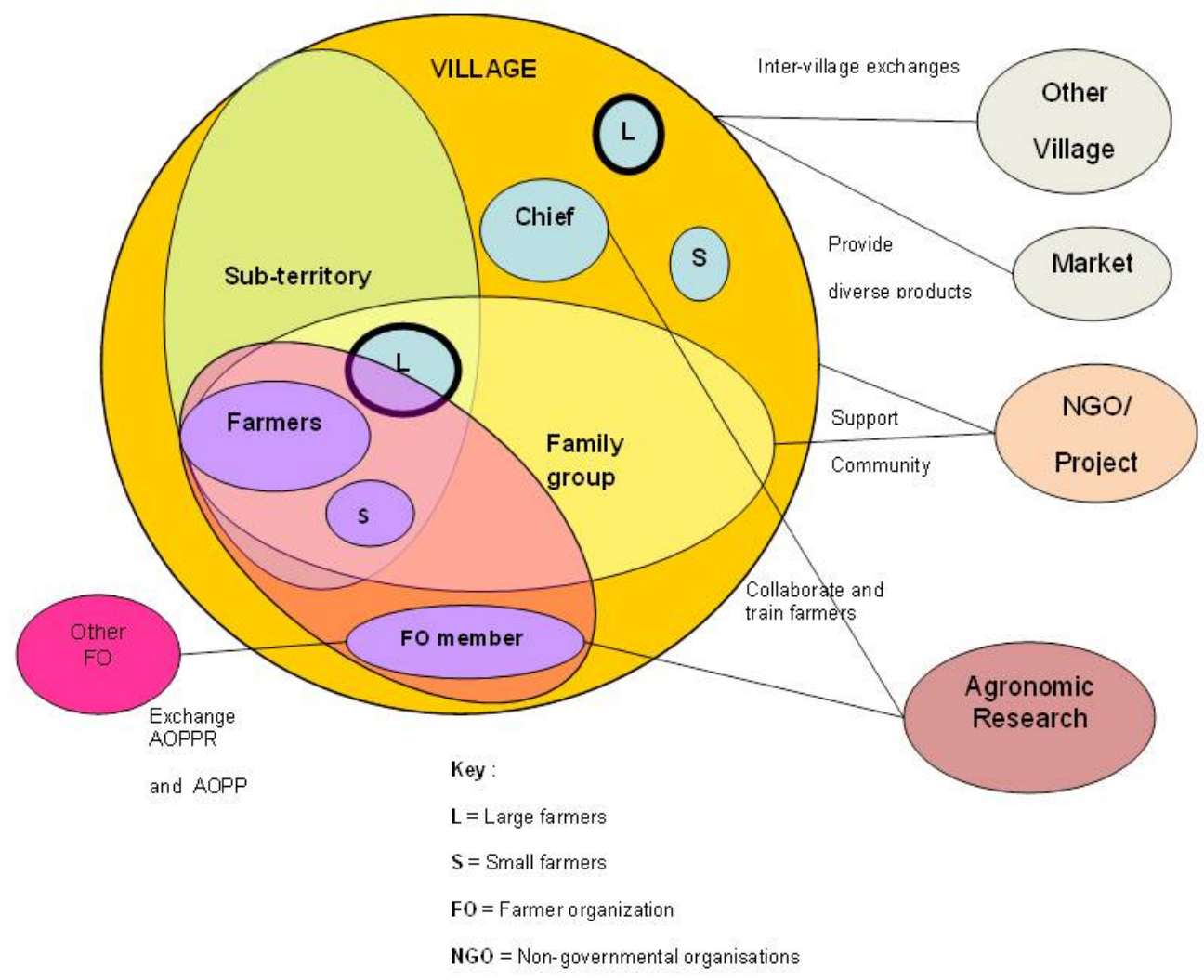

Figure 1. Diagram of social relations between actors in a village (adapted from Bazile and Abrami, 2008)

In the villages, farmers supply themselves with pearl millet and sorghum seeds in several ways. Alongside annual self-production (about 90\%), farmers seek seeds at harvest time, during the dry season, or when seedlings are planted from their family groups, neighbours, development agencies, projects, or farmer organizations (FO). The seed management system is based on a network of non-market exchanges (self-production, inheritance, gift, trade, ...) between farmers from the farm level up to the level of the small natural region, with seed qualities varying according to the care given by each farmer (Coulibaly, 2011). It seems that the conservation of pearl millet and sorghum varieties is mainly ensured by an informal seed system in which the farmers are the sole actors. It is the multiplicity and diversity of individual practices that allows the farmer-based selection and maintenance of local varieties, which takes place without the actors in the system formally coming together to agree on shared objectives.

In response to the challenge of food insecurity in Mali, several modes of production and dissemination of "improved" pearl millet and sorghum seeds have been developed. The country currently is seeking to increase production based on new research varieties, which are considered to be more productive, without losing existing agricultural biodiversity, which constitutes a national heritage.

\subsection{Formal Seed Sector Distribution}

The formal seed sector distributes certified seeds through cooperatives with cost-effectiveness as the main objective.

Until recently (2005), the formal seed sector in Mali was restricted to state structures. This sector has always been guided by a large number of public policies involving institutional, legal, and regulatory domains. The agricultural development strategy adopted by Mali aims for the diversification of food production and poverty reduction by reinforcing food security through the development of agricultural commodities. The development of the seed sector in Mali falls within this overall public policy framework for agriculture. It has gone through numerous changes through the creation of different institutions, projects, and development operations to improve the management of the formal state seed system.

The production of certified seeds remains within the purview of the formal seed system, which oversees seed production and distribution following strict, well-defined, and regulated methodologies and standards. Seed 
multiplications are managed according to national and/or international laws (Louwaars et al., 1996).

Recent changes in the seed sector made it possible for two types of seed cooperatives to emerge: decentralized cooperatives under a national seed service (SSN) and association-based cooperatives under AOPP, the umbrella organization of farmer organizations in Mali.

Diverse actors now play a role in the certified seed production/distribution process. They include the National Directorate of Agriculture (DNA), the Institute of Rural Economics (IER), the Regional Directorates of Agriculture (DRA), the National Seed Service (SSN), the seed laboratory (Labo Sem), the two types of seed cooperatives described above, Rural Development Offices (ODR) and NGOs (Table 2).

Table 2. Main actors in the seed sector in Mali

\begin{tabular}{|c|c|}
\hline Services & Role/Function in the seed system \\
\hline $\begin{array}{c}\text { DNA } \\
\text { (National Agriculture Division) }\end{array}$ & $\begin{array}{l}\text { Under the Ministry of Agriculture, the DNA implements agriculture policy in Mali, fixes } \\
\text { objectives and production standards, updates the official catalogue of varieties. }\end{array}$ \\
\hline $\begin{array}{c}\text { DRA } \\
\text { (Regional Agriculture Office) }\end{array}$ & $\begin{array}{l}\text { Under the DNA, they carry out DNA activities at the regional administration level. } \\
\text { DRAs identify farmers needs for basic seeds, first generation (R1) and second } \\
\text { generation (R2) certified seeds of cooperatives, and transmit this information to the } \\
\text { DNA, which provides these data to the SSN (National Seed Service). They participate in } \\
\text { the field supervision of seed multiplication fields and, with LaboSem, take production } \\
\text { samples for laboratory analysis. They provide support to farmers and help in the } \\
\text { dissemination of selected varieties. }\end{array}$ \\
\hline $\begin{array}{l}\text { LaboSem } \\
\text { (Seed laboratory) }\end{array}$ & $\begin{array}{l}\text { Also under the DNA, the seed laboratory carries out field controls and analyses of seeds } \\
\text { produced by the cooperatives. Following this work, it certifies or rejects the seeds. }\end{array}$ \\
\hline $\begin{array}{c}\text { IER } \\
\text { (Institute of Rural Economics) }\end{array}$ & $\begin{array}{l}\text { IER is responsible for introducing, creating, and improving varieties. IER provides SSN } \\
\text { with basic seeds for the R1 production needs of satellite SSN cooperatives. }\end{array}$ \\
\hline SSN (National Seed Service) & $\begin{array}{l}\text { Under the DNA, the service oversees the coordination of the national seed plan. It } \\
\text { includes } 6 \text { seed multiplication satellites, of which } 3 \text { are for millet and sorghum. It } \\
\text { presents the basic seed production program to IER. It supervises the production of R1 } \\
\text { seeds of satellite cooperatives and R } 2 \text { seeds for planting with the local seed cooperatives. } \\
\text { SSN provides support and advice to seed farmers and contributes to the marketing of } \\
\text { certified seeds. }\end{array}$ \\
\hline $\begin{array}{l}\text { Decentralized SSN Seed } \\
\text { Producer Cooperatives }\end{array}$ & $\begin{array}{l}\text { They produce certified R1 and R2 seeds under the supervision of SSN satellites and the } \\
\text { DRAs. The R } 1 \text { of satellites are sold to cooperatives to produce R2 in their local areas. } \\
\text { They can access credit (inputs and marketing) from the National Agriculture } \\
\text { Development Bank (BNDA). After the certification of R } 2 \text { seeds, each cooperative sells } \\
\text { its production. }\end{array}$ \\
\hline $\begin{array}{c}\text { AOPP Seed Producer } \\
\text { Cooperatives (Association of } \\
\text { Farmers'Organizations of Mali) }\end{array}$ & $\begin{array}{l}\text { AOPP examines the problems of farmers with government authorities and circulates } \\
\text { development information in rural areas. Since } 2005 \text {, it disseminates improved seeds } \\
\text { through its own network of farmer organizations. AOPP obtains basic seeds from DRA } \\
\text { and R1 seeds from SSN satellites and, have them multiplied by farmer seed producers } \\
\text { who are members of a FO to produce R } 2 \text { seeds. After certification, it sells the R2 seeds } \\
\text { produced by member cooperatives }\end{array}$ \\
\hline $\begin{array}{c}\text { ODR (Rural Development } \\
\text { Offices) and NGO } \\
\text { (Non-governmental organization) }\end{array}$ & ODRs and NGOs disseminate improved seeds in their project areas \\
\hline
\end{tabular}

The pearl millet and sorghum seed system is characterized by a multiplicity of actors acting at different levels and very influential social networks, leading to highly diverse social and ecological interactions. A network of 139 decentralized cooperatives oversees the multiplication and distribution of SSN seeds while AOPP intervenes through 8 cooperatives which are all located in the Ségou Region.

In this network's collection of catelogued improved varieties, we counted 32 varieties of pearl millet and 57 varieties of sorghum in Mali (CILSS, 2008). Two improved pearl millet varieties (Toroniou C1 and Benkadinio) were multiplied in 2007 by SSN seed farmers while the AOPP network produced three varieties (Toroniou C1, Soxat and Indiana 05). During the same period, the state system multiplied CSM63 E and CSM 417 sorghum variety seeds while the AOPP network produced the Zarrablen, Sankatiki and Darellken varieties. The seed multiplication work undertaken by each type of cooperative thus is complementary, responding respectively to the advice of government technical services or to particular requests from $\mathrm{FO}$ members. 
However, based on the results of our 2011 surveys, it appears that with the exception of SSN cooperatives, almost all of the decentralized cooperatives function poorly, or at least not as well as when they were first set up; this negative turn follows the end of the PAFISM project in 2009. The various forms of state support ended and there is now no coherent framework for the management of the cooperatives' resources. The few that are still operating are supported by other partners, such as: AGRA (Alliance for a Green Revolution in Africa), PDRN (Nebrica rice development project), WASA (West Africa Seed Alliance), Sasakawa Global 2000 and IICEM (Integrated initiatives for economic growth in Mali). However, Mali is actively participating at the West African regional level in actions to harmonize regulatory frameworks for the production, quality control, and trade of seeds, and the establishment of joint catalogues for member countries of the Permanent Inter-State Committee for Drought Control in the Sahel (CILSS), the West African Economic and Monetary Union (UEMOA) and the Economic Community Of West African States (CEDEAO). These actions seek to promote the seed trade and improve seed production based on harmonized standards and analytic methods.

The question that remains unanswered is how can the different systems position themselves in relation to each other to better respond to farming diversity through a diversified supply of seed types?

\section{Discussion: Seed Systems Positioned to Better Manage Varietal Diversity}

\subsection{Systems With Specific Objectives}

The intensification of agriculture is a major threat to traditional varieties which do not respond to the specifications and technical standards required of improved varieties. In the overall context of the spread of improved seeds, it is necessary to seek complex solutions able to limit the negative impact of the diffusion of improved seeds on the maintenance of biodiversity.

The traditional farmer seed supply system, one that is non-commercial, informal, and based on a principle of mutual support, includes methods to select, produce, conserve and distribute local pearl millet and sorghum seeds. As a general rule, each farmer manages one to three varieties. These have the characteristics needed to be planted on his farm in a normal climate year and suit his family's needs. The reproduction of seeds is made each year in the field by an appointed, experienced person on the farm. In this system, there is no particular seed quality control to meet certain collective rules. The farmer selects and conserves his seeds as best he can, his choices informed by his own needs the following year. Seed production falls within the individual framework of the farm: self-production is involved, only that in excess to what a farmer has defined as his future needs is available to those who may request it. This is why the acquisition of seeds is subject only to the quality rules of the supplier. The person acquiring the seeds consequently must assume the task of inspection when she receives and/or sows the seeds.

The formal seed system produces certified, improved pearl millet and sorghum seeds with the aim of providing high yield varieties to interested farmers. To ensure sustained operations, the formal seed system must reap profits from the sale of these seeds. As the products are sold on the market, the inspection and certification of seed quality is ensured by a specialized, independent service, which in Mali is the Seed Laboratory (Niangado, 2002; Coulibaly et al., 2008).

However, the majority of farmers do not possess existing and available information on the improved varieties. The current improved varieties are mainly obtained by eliminating photoperiod sensitivity. In order to create short-cycle varieties, fixed-cycle varieties were produced (therefore ones that are not photoperiodical). This characteristic renders it possible to cultivate improved varieties in a wide range of latitudes, and even off-season. The varieties produced are homogeneous due to their limited genetic base. The new features of these varieties linked to the loss of photosensitivity require the strict application of particular technical schedules (dates of sowing, fertilization, ploughing, maintenance, pesticide treatments). These are necessary to guarantee the success of the crop but they often are ill suited to the cropping conditions (both agronomic and socio-economic) faced by farmers.

Despite the formal seed system's concern for profits, the sale price of improved seeds is not based on a calculation of the real cost price. This is determined above all by seed sector support policies. The distribution networks are currently made up of stores built with the support of projects. The seeds are largely purchased in small quantities by farmers for their own use over the year underway and often are multiplied by the farmers in the following years. The pearl millet and sorghum seed market in Mali thus remains today little developed. It continues to be articulated around the demands, often not honored, of areas served by farm extension technical services, periodic and irregular requests from certain NGOs for occasional projects and, in an accessory manner, the needs of emergency programs such as the World Food Program (WFP). 


\subsection{A Very Centralized Formal Seed Systems}

The attempt to disseminate improved pearl millet and sorghum varieties through the state seed networks failed in the main farming areas of southern Mali (Sissoko et al., 2008; Siart, 2008). This system is highly centralized and relies on official agencies under the Ministry of Agriculture (Figure 2).

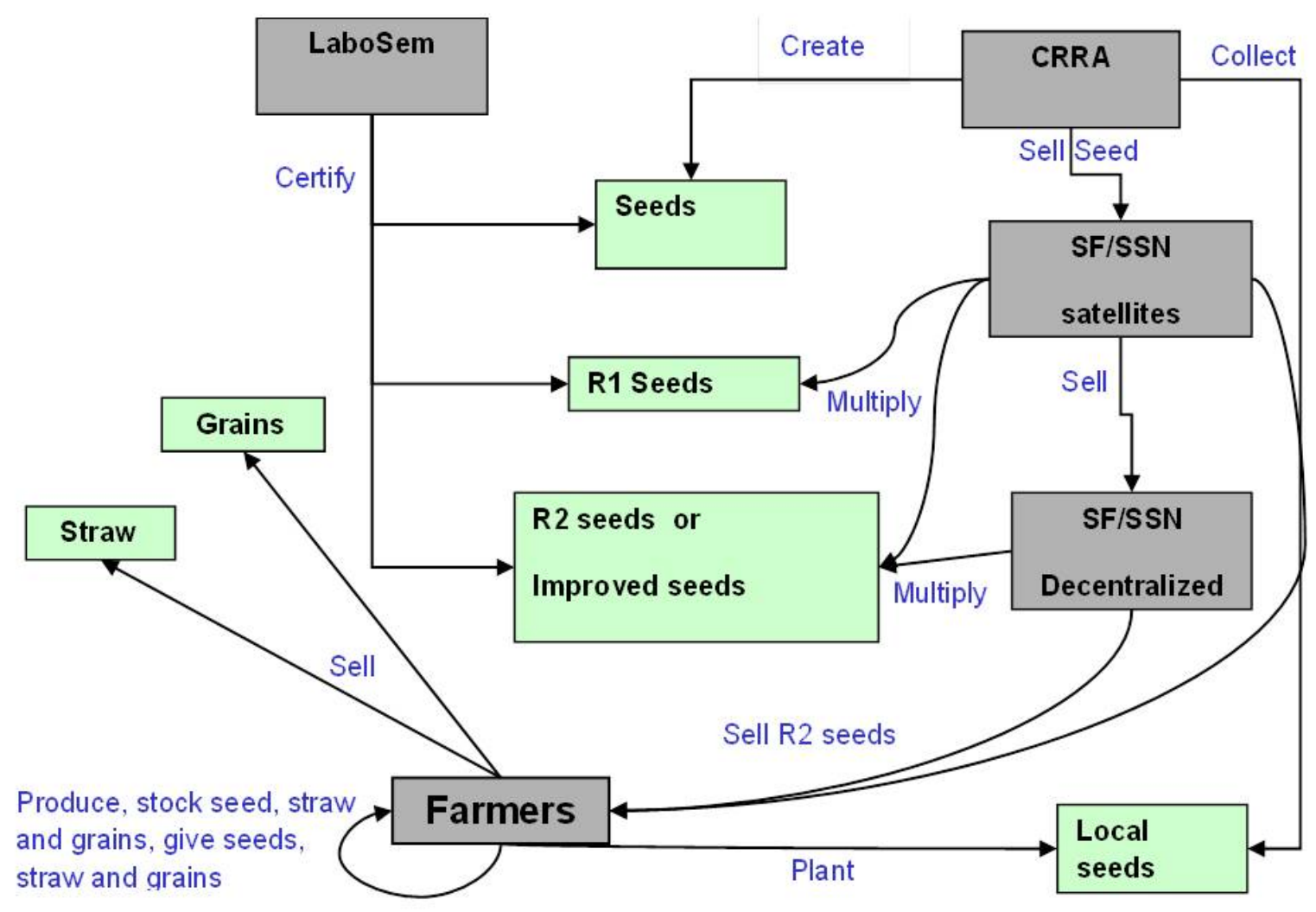

Figure 2. Diagram of interactions between farmer and state seed systems

Key: CRRA (regional agronomy research center);

SF (seed farmer); R1 and R2 (first and second reproduction seeds).

Satellite seed farmers are supervised by SSN technicians and receive seasonal loans to produce R1 and R2 seeds. The production of these seeds is very high and involves very few varieties (2 varieties of each species for the two satellites). The satellite farmers are the main users of these seeds and this most often engenders the disappearance of local varieties. Apart from sporadic purchases by NGOs and projects, these cooperatives must manage large quantities of unsold seeds ( $900 \mathrm{~kg}$ of R1 and $1.522 \mathrm{~kg}$ of R2 for the Babougou cooperative; 7.378 $\mathrm{kg}$ of R1 and $6.823 \mathrm{~kg}$ of R2 for the Sobala (M'Pèssoba) cooperative in 2007).

In 2011, the total production of pearl millet and sorghum seeds was, for R1 and R2 respectively, $1.108 \mathrm{~kg}$ and $4.091 \mathrm{~kg}$ in Babougou and $1.636 \mathrm{~kg}$ and $1.185 \mathrm{~kg}$ in Sobala.

The decentralized cooperatives set up by seed farmers in agricultural areas are in charge of the production of R2 seeds destined to be planted. After being certified by the seed laboratory, each cooperative sells its R2 seeds to farmers. The amount produced is small and the flow of seeds remains very limited.

The AOPP seed system relies on its close proximity to members while remaining connected to state services.

Under the framework of the farmer organizations seed network (Figure 3), the dissemination of certified seeds is successfully conducted through their member networks, which then disseminate the seeds more widely through the social network of the acquiring farm. Each member of a FO systematically represents a separate family farm. The farmer organization encourages exchanges of experience regarding the management of varieties, local and 
improved, sown on the farm scale. Members of the network then promote the circulation of varieties beyond the limited scale of the village, reaching beyond the regional level and up to the national scale. The sale prices of the seeds disseminated is set lower than those applied by SSN cooperatives. AOPP masters its mechanism to multiply, distribute, and market seeds, and supplies farmers with quality seeds adapted to their agro-ecological area.

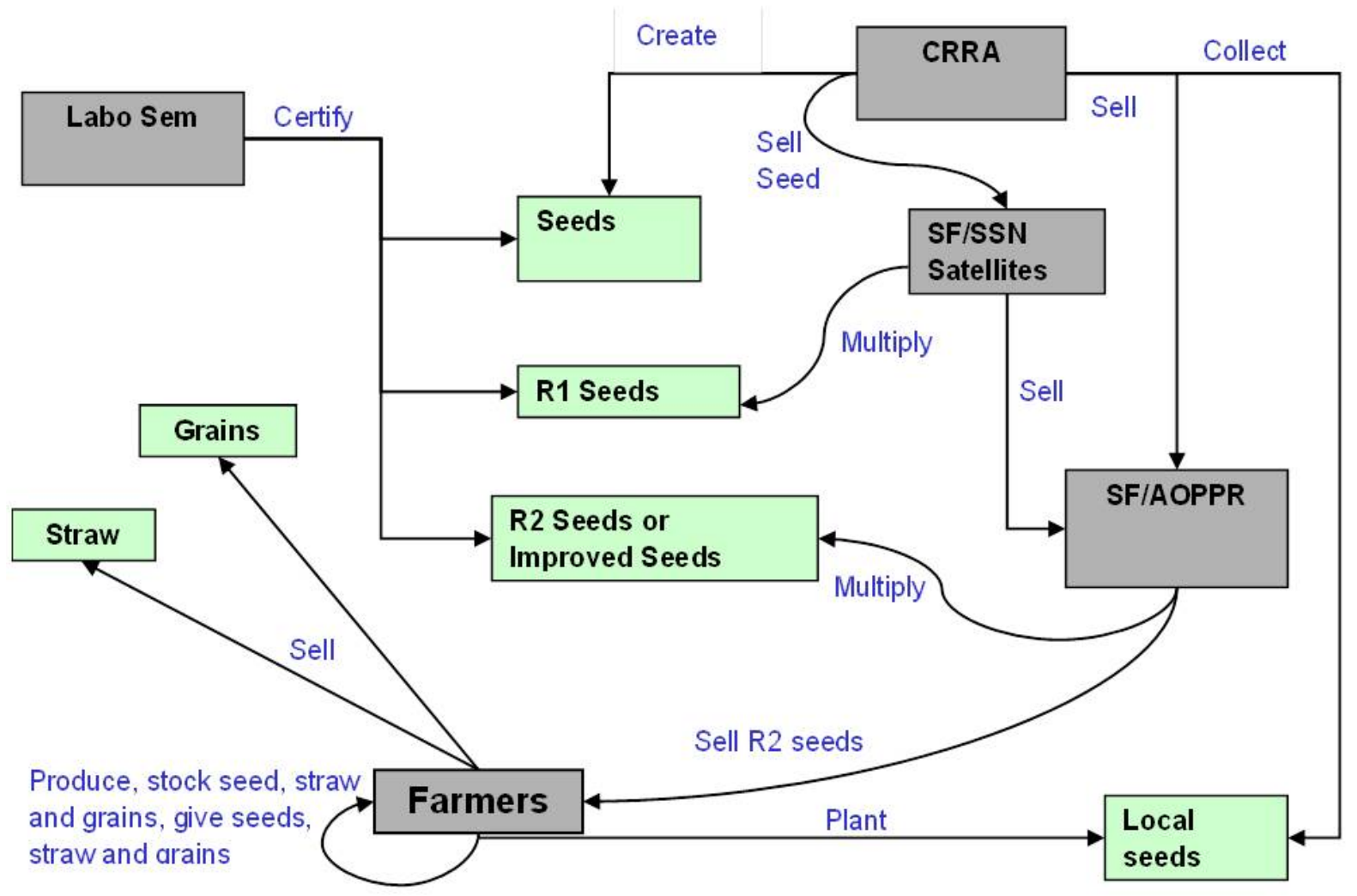

Figure 3. Diagram of interactions between farmer seed systems and SS/AOPP

Key: CRRA (regional agronomy research center);

SF/AOPPR (AOPP seed farmer at the regional level); R1 and R2 (first and second reproduction seeds).

The production of $\mathrm{R} 2$ seeds is ensured by the AOPPR seed farmers of Ségou. The R2 seeds thus produced are first sold to members of farmer organization cooperatives and then to other farmers in their area or elsewhere.

The seed production of these cooperatives remains small but responds to the demand of famers from different agro-ecological areas and involves a greater number of varieties (3 varieties of each species for the two cooperatives) compared to the state system.

Furthermore, AOPP allows FOs to access information that is not available in the villages. The FOs thereby acquire knowledge and recognition that allows them to influence decisions taken by national level agricultural bodies (Bazile, 2006).

\subsection{Towards a Global Seed System}

The AOPP associative seed system network lies at the conjunction between farmer and formal state seed systems. The FOs' local-based distribution network is effective and forms a link between formal state seed systems and farmers' traditional systems. It relies on an agro-ecological vision of crop areas as well as locally legitimate organizations. This combination allows the emergence of a global seed system which includes farmer and state seed systems that are a priori independent.

The management of agrobiodiversity raises the problem of how to simultaneously consider the viewpoints of the 
diverse actors involved in cultivation systems. It is through the interaction of farmer, market, and institutional supply systems that new forms of varietal diversity management may be identified.

By analyzing the diagrams presenting the interactions between state and farmer organizations' seed systems with the farmer seed system in Mali, it is possible to identify points that could contribute to the creation of a global seed system integrating the existing participants. The diagram of interactions between the actors and seeds of the SSN and SS/AOPP (Figure 4) enables one to visualize the consequences of these interactions according to the range of viewpoints gathered during the surveys.

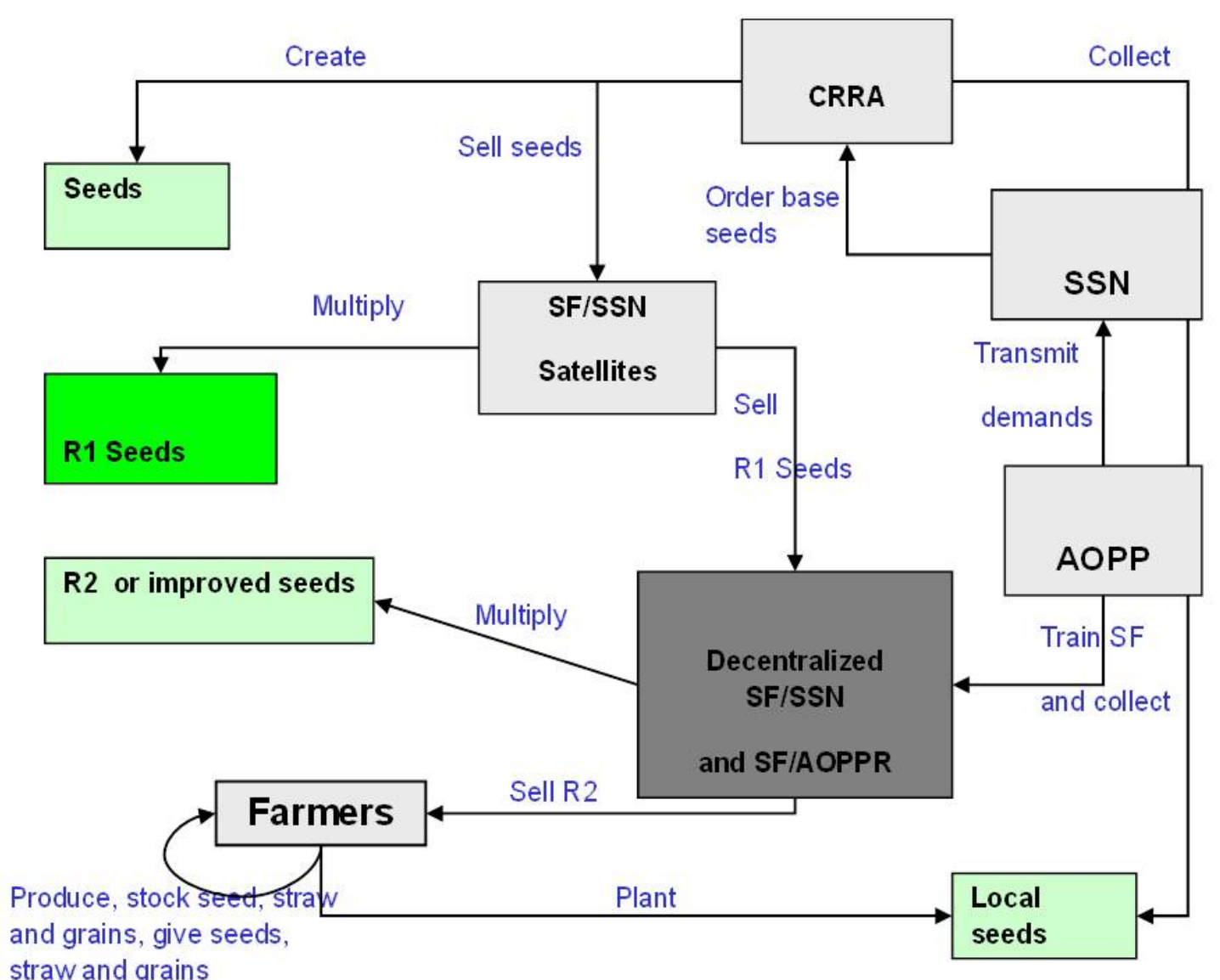

Figure 4. Graphic diagram of a global seed system

The AOPP network, operating at the interface between farmer seed systems and the SSN, enables the supply of improved seeds to farmers to be improved through a global network (Coulibaly et al., 2008).

Such a seed network could be functional if certain conditions are met regarding collaboration. Three key elements would allow an effective link to be established between seed networks and promote the sustainable management of plant genetic resources.

- The first involves the maintenance of satellite seed producers, with their long experience in seed production techniques, as producers/distributors of R1 seeds. Having inherited infrastructure from the SSN, they are capable of fully ensuring their role and respond to demands from different areas for varieties. Furthermore, these seed producers also produce R2 seeds of varieties that are desired by farmers in their own areas. In contrast, the production/distribution of the R2 seeds of decentralized cooperatives must be entrusted to AOPP seed producers who intervene at the level of the communes and villages to respond to local demands. The production of AOPP cooperatives is based on the satisfaction of seed needs adapted to the micro-environments of their members. AOPP's distribution approach is based on the demands coming from local communities. The SSN network of decentralized seed producing farmers either should be associated with the AOPP cooperative or removed to allow AOPP seed producers to produce R2 in their agro-ecological areas. Adequate knowledge of varieties, 
based on characteristics adapted to the agro-ecologies corresponding to the cultivation systems developed by farm families, thus constitutes the first element connecting seed systems. Cooperatives producing R2 seeds would play a beneficial role in communities by reducing distrust between the actors in the supply networks. In the formal seed systems, objectives to distribute seeds produced by the cooperatives take priority over collaboration in order for state institutions to be as profitable as possible. This is contrary to good seed coverage for farmers because marketing priorities take precedence over adapting varieties to ecological areas. The transfer of $\mathrm{R} 2$ production to the AOPP seed system resolves this problem, which is why the duplication of services by the two types of cooperatives (SSN and AOPP) must be avoided at all costs. Avoiding competition between the cooperatives of the two systems will improve the global system's ability to provide the best adapted seeds to farmers.

- Technical agents in the different networks must continue to provide support to farmers but the SSN staff should be reduced while that of AOPP increased to enable the coverage to be closer to the communities and more responsive to their expectations. Under these conditions, the circulation of agricultural information will be directed towards the farmers and the varieties disseminated will be better adapted to their needs. Malian farms are part of a production system based on multiple social networks through which plant genetic material is exchanged. The social ties between communities consequently will be reinforced by FO members. The support given to seed farmers by technical services constitutes the second element connecting the systems, coming in the form of support and training in the selection-multiplication of seeds.

- The maintenance of local varieties by farmers is based on their own on-farm management of traditional cereal crops and constitutes the third connecting element in seed networks, with an objective of in situ conservation. Varietal diversity, seen both as a heritage and vital resource for rural populations, constitutes a reservoir of genetic diversity that is relatively accessible to researchers. However, farmers do not have the means to control the evolution of varieties or plan conservative and rational management for the ensemble of interests in society. It thus is necessary to consider how this work for the common good realized individually by farmers could be compensated, even symbolically, to generate recognition of the role played by family farms for society; and this to find mechanisms enabling farmers to sustain themselves while conserving these functions. Two factors would favour this:

- Dynamizing seed activities should make it easier to learn about the diversity of local and improved seeds available to farmers in a given region.

- A good institutional foundation and the support of AOPP legitimize the process, but seeds must be proposed at prices farmers can afford.

Farmer organizations actively participate in the supply of improved seeds to their members and accelerate the pace of traditional exchanges. Due to their local reputation, which gives them legitimacy, FOs sometimes serve as seed testing models in a given area. The farmer who acquires a variety from a FO can skip testing it due to the confidence awarded the FO. In this context, he can directly replace a local variety with an improved variety from one year to another. This is why it is important to well understand the relationships of farmer seed systems, the SSN, and FOs because a leading farmer with a local following could induce the massive dissemination of a single improved variety, and thereby contribute to genetic erosion and the loss of diversity of local varieties.

\section{Conclusion}

The articulation of the state seed system and the traditional seed systems of farmers appears to be a plausible alternative. Conceptual ARDI modelling made it possible to establish diagrams promoting the main actors to work together to analyse the dynamics of resources produced from interactions between actors and the types of resources according to different environments. This methodology invites seed actors to recognize the stakes involved in both production and conservation in order to adopt a collective approach to the dynamic management of cultivated varieties.

A dry cereal seed system that is efficient and able to supply Malian farmers at a low cost throughout the country is nevertheless only possible within the framework of an integrated seed policy. The objectives of different stakeholders at different scales must be taken into account while keeping in mind the permanent need to evolve and adapt to family farms. Solutions for the dysfunctions analysed require a coordinated seed policy between the actors identified within the different networks. The most efficient alternative system for the dissemination of seeds and the simultaneous conservation of agro-biodiversity appears to be one which combines elements of the formal and informal systems, state, association, and farmer. This would ensure a dynamic management of cultivated varieties able to adapt to future environmental and socio-economic changes. As the state withdraws from the production/dissemination of certified seeds, the reinforcement of the capacities of new actors is 
indispensable.

The present study analyses the functioning of farmer and formal seed networks, evaluates their impacts on agro-biodiversity, and proposes an inclusive global seed production system. The state system is heavily administrative and does not provide a range of improved varieties adapted to different farmer environments. However, while farmer seed systems cover about $90 \%$ of seed production, each system is limited in general by the geographic area of a small natural region. Furthermore, they disseminate seeds whose quality varies according to the care given to their selection by different farmers. AOPP successfully produces and disseminates improved seeds to farmers in Mali after testing them. A new network covering the interfaces between the state and farmer systems would improve seed supply to farmers by creating a link between the two a priori independent systems. Major challenges to this global seed system are: its autonomization, profitability, contribution to the preservation of biological diversity and ensuring food security for family farmers in Africa.

\section{Acknowledgements}

The authors wish to express their appreciation to farmers who cared for their seeds for telling us their stories, and also to projects that made possible funding of reported research activities IMAS (ANR07 BDIV 016-01) and "Management of the Agrobiodiversity in Mali" (AFD/FFEM). We would like to thank Grace Delobel for translating and editing our article. In addition, the authors thank the anonymous reviewers for all their comments.

\section{References}

Abrami, G., Bazile, D., Trébuil, G., Le Page, C., Bousquet, F., Dionnet, M., \& Vejpas, C. (2008). Accompagner l'évolution des systèmes semenciers céréaliers au Mali et en Thaïlande. Cahiers Agricultures, 17(2), 210-215. http://dx.doi.org/10.1684/agr.2008.0166

Almekinders, C. J. M., Louwaars, N. P., \& De Bruijn, G. H., (1994). Local Seed Systems and their importance for Improved Seed Supply in Developing Countries. Euphytica, 78, 207-216. http://dx.doi.org/10.1007/BF00027519

Almekinders, C. J. M., \& Louwaars, N. P. (2002). The importance of the farmers' seed systems in a functional national seed sector. J New Seeds, 4, 15-33. http://dx.doi.org/10.1300/J153v04n01_02

Altieri, M. A. (2002). Agroecología: the science of natural resource management for poor farmers in marginal $\begin{array}{lllll}\text { environments. Agriculture, Ecosystems and } & \text { Environment, }\end{array}$ http://dx.doi.org/10.1016/S0167-8809(02)00085-3

Altieri, M. A. (2004). Linking ecologists and traditional farmers in the search for sustainable agriculture. $\begin{array}{lllll}\text { Frontiers in Ecology and 2, } & \text { Environment, }\end{array}$ http://dx.doi.org/10.1890/1540-9295(2004)002[0035:LEATFI]2.0.CO;2

Barnaud, A. (2007). Savoirs, pratiques et dynamique de la diversité génétique: le sorgho (Sorghum bicolor ssp. bicolor) chez les Duupa du nord Cameroun. Thèse de doctorat en Biologie des populations, Université de Montpellier II, p. 231.

Bazile, D. (2006). State-farmer partnerships for seed diversity in Mali. Londres : IIED, p. 22 (Gatekeeper Series : IIED, 127). Retrieved from http://www.iied.org/pubs/pdf/full/14519IIED.pdf

Bazile, D., \& Soumaré, M. (2004). Pratiques paysannes de gestion de la diversité variétale en réponse à la diversité écosystémique. Le cas du sorgho [Sorghum bicolor (L) Moench] au Mali. Étude Originale. Cahiers Agricultures, 13, 480-487.

Bazile, D., \& Abrami, G. (2008). Des modèles pour analyser ensemble les dynamiques variétales du sorgho dans un village malien. Cahiers Agricultures, 17(2), 203-209. http://dx.doi.org/10.1684/agr.2008.0171

Bazile, D., Dembélé, S., Soumaré, M., \& Dembélé, D. (2008). Utilisation de la diversité variétéale du sorgho pour valoriser la diversité des sols au Mali. Cahiers Agricultures, 17(2), 86-94. http://dx.doi.org/10.1684/agr.2008.0172

Bocci, R., \& Chable, V. (2008). Semences paysannes en Europe: enjeux et perspectives. Option réseaux d'échanges. Cahiers Agricultures, 17(2), 216-221. http://dx.doi.org/10.1684/ agr.2008.0173

Bousquet, F., Barreteau, O., Aquino (d'), P., Etienne, M., Boissau, S., Aubert, S., ... Castella, J.-C. (2003). Multi-agent systems and role games: collective learning processes for ecosystem management. In: Janssen, M. (Ed.), Complexity and Ecosystem Management: The Theory and Practice of Multi-Agent Approaches. Edward Elgar Publishers, pp. 248-285.

Brush, S. B. (1991). A farmer-based approach to conserving crop germplasm. Economic Botany, 45, 153-65. 
http://dx.doi.org/10.1007/BF02862044

Brush, S. B. (1995). In situ conservation of landraces in centres of crop diversity. Crop Science, 35, 346-354. http://dx.doi.org/10.2135/cropsci1995.0011183X003500020009x

Caillon, S. (2005). Pour une conservation dynamique de l'agro biodiversité. Gestion de la diversité variétale d'un arbre " des Blancs 》 (cocotier, Cocos nucifera L.) et d'une plante des " ancêtres 》 (taro, Colocasia esculenta (L.) Schott) au Vanuatu. Thèse de doctorat en Géographie, Université d'Orléans, p. 419, 272. d'annexes.

Ceccarelli, S. (1994). Specific adaptation and breeding for marginal conditions. Euphytica, 77, 205-220. http://dx.doi.org/10.1007/BF02262633

Clawson, D. L. (1985). Harvest Security and Intra-Specific Diversity in Traditional Tropical Agriculture. Economic Botany, 39, 56. http://dx.doi.org/10.1007/BF02861175

Cleveland, D. A., Soleri, D., \& Smith, S. E. (1994). Do folk crop varieties have a role in sustainable agriculture? Bioscience, 44, 740-51. http://dx.doi.org/10.2307/1312583

Coulibaly, H., Bazile, D., Sidibé, A., \& Abrami, G. (2008). Les systèmes d'approvisionnement en semences de mils et sorghos au Mali: production, diffusion et conservation des variétés en milieu paysan. Notes de

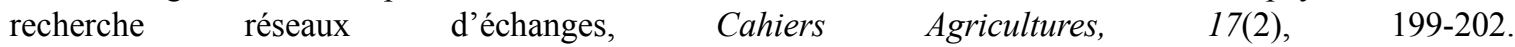
http://dx.doi.org/10.1684/agr.2008.0177

Coulibaly, H. (2011). Rôle des Organisations Paysannes dans la diffusion de semences de céréales : articulation des réseaux semenciers formel étatique et traditionnels paysans pour une conservation in situ des variétés. Cas des mils et sorghos au Mali -, PhD thesis, Paris Ouest Nanterre, p. 296.

de Boef, W. S., Dempewolf, H., Byakweli, J-M., \& Marie Engels, J. M. (2010). Integrating Genetic Resource Conservation and Sustainable Development into Strategies to Increase the Robustness of Seed Systems. Journal of Sustainable Agriculture, 34(5), 504-531. http://dx.doi.org/10.1080/10440046.2010.484689

Daré, W., Ducrot, R., Botta, A., \& Etienne, M. (2009). Repères méthodologiques pour la mise en æuvre d'une démarche de modélisation d'accompagnement, Commod: Montpellier, France, p. 127.

David, S., Mukandala, L., \& Mafuru, J. (2002). Seed Availability, an Ignored Factor in Crop Varietal Adoption Studies: A Case Study of Beans in Tanzania, Journal of Sustainable Agriculture, 21(2), 5-20. http://dx.doi.org/10.1300/J064v21n02_03

Deu, M., Sagnard, F., Chantereau, J., Calatayud, C., Vigouroux, Y., Pham, J. L., \& Bezancon, G. (2010). Spatio-temporal dynamics of genetic diversity in Sorghum bicolor in Niger. Theor Appl Genet, 120, 1301-1313. http://dx.doi.org/10.1007/s00122-009-1257-1

Deu, M., Weltzien, E., Calatayuda, C., Traoré, Y., Bazile, D., Gozé, E>, \& vom Brocke, K. (2014). How an improved sorghum variety evolves in a traditional seed system in Mali: Effects of farmers' practices on the maintenance of phenotype and genetic composition. Field Crop Research In Press, Corrected Proof, Available online 23 August 2014.

Dudnik, N. S., Thormann, I., \& Hodgkins, T. (2001). The extent of use of plant genetic ressources in research. A literature survey. Crop science, 41, 6-10. http://dx.doi.org/10.2135/cropsci2001.4116

Etienne, M. (2006). La modélisation d'accompagnement : un outil de dialogue et de concertation dans les réserves de biosphère. Biodiversité et acteurs, des itinéraires de concertation. UNESCO-MAB, Réserves de Biosphère, note technique 1-2006, 44-52.

Etienne M. (editor). (2011). A Participatory Approach Supporting Sustainable Development. QUAE éditions: Paris (France).

Etienne, M., Du Toit, D. R., \& Pollard, S. (2011). ARDI: a co-construction method for participatory modelling in natural resources management. Ecology and Society, 16(1), 44. Retrieved from http://www.ecologyandsociety.org/vol16/iss1/art44/

Fonteneau, A., Dulloo, E., \& Sidibé, A. (2005). Linking farmers and genebanks in Mali. Geneflows: p. 24.

Lacy, S. M., Cleveland, D. A., \& Soleri, D. (2006). Farmer choice of sorghum varieties in Southern Mali. Human Ecology, 34(3), 331-353. http://dx.doi.org/10.1007/s10745-006-9021-5

Longley, C., Dominguez, C., Saide, M. A., \& Leonardo, W. J. (2002). Do farmers need relief seed? A methodology for assessing seed systems. Disasters, 26, 343-55. http://dx.doi.org/10.1111/1467-7717.00211 
Louwaars, N. P., \& Van Marrewijik, G. A. M. (1996). Seed Supply Systems in Developing Countries, CTA: Paris (FR) p. 142.

Matlon, P. J. (1985). Analyse critique des objectifs, méthodes et progrès accomplis à ce jour dans l'amélioration du sorgho et du mil : une étude de cas de l'ICRISAT/Burkina Faso. In H. W. Ohm \& J. G. Nagy (Eds.), Technologies appropriées pour les paysans des zones semi-arides d'Afrique de l'Ouest. (pp. 181-211). Purdue University, West Lafayette, Indiana (USA).

McGuire, S. (2005). Getting genes: Rethinking seed system analysis and reform for sorghum in Ethiopia. $\mathrm{PhD}$ Thesis. Wageningen University.

Naville. (2005). La biodiversité des espèces cultivées: Analyse dans le cas du blé. Boutique des sciences, p. 20.

Niangado O. (2002). Commerce, propriété intellectuelle \& développement durable vus de l'Afrique (pp. 127-141). ICTSD, Enda, Solagral.

Pham, J-L., \& et van Hintum T., (2000). Genetic diversity in agro-ecosystems. In: C. Almekinders \& W. De Boef (eds.), Encouraging diversity. The conservation and development of plant genetic resources (pp 8-14). Londres, Intermediate Technology Publications.

Pretty, J., Morrison, J I. L., \& Hine, R. E. (2003). Reducing food poverty by increasing agricultural sustainability in developing countries. Agriculture, Ecosystems and Environment, 95, 217-234. http://dx.doi.org/10.1016/S0167-8809(02)00087-7

Quang, T. H., Hong, C. N., Thanh, B. T., Ignacio, N., \& Berg, T. (2011). Impacts of Seed Clubs in Ensuring Local Seed Systems in the Mekong Delta, Vietnam, Journal of Sustainable Agriculture, 35(8), 840-854. http://dx.doi.org/10.1080/10440046.2011.611746

Sagnard, F., Barnaud, A., Deu, M., Barro, C., Luce, C., Billot, C., \& Vaksmann, M., (2008). Analyse multiéchelle de la diversité génétique des sorghos: compréhension des processus évolutifs pour la conservation in situ. Cahiers Agricultures, 17(2), 114-121. http://dx.doi.org/10.1684/agr.2008.0180

Siart, S. (2008). Strengthening Local Seed Systems, Options for Enhancing Diffusion of Varietal Diversity of Sorghum in Southern Mali. Kommunikation und Beratung n 85. Margraf Publishers, p. 185.

Sissoko, S., Doumbia, S., Vaksmann, M., Hocdé, H., Bazile, D., Sogoba, B., \& Dicko, B.-G. (2008). Prise en compte des savoirs paysans en matière de choix variétal dans un programme de sélection. Cahiers Agricultures, 17(2), 128-133. http://dx.doi.org/10.1684/agr.2008.0191

Soumaré, M., Kouressy, M., Vaksmann, M., Maïkano, I., Bazile, D., Traoré, P. S., \& Barro, K. C. P., (2008). Prévision de l'aire de diffusion des sorghos photopériodiques en Afrique de l'Ouest. Cahiers Agricultures, 17(2), 160-171. http://dx.doi.org/10.1684/agr.2008.0183

Sperling, L., \& Loevinsohn, M. E. (1993). The dynamics of adoption: distribution and mortality of bean varieties among small farmers Rwanda. Agricultural Systems, 41, 441-453. http://dx.doi.org/10.1016/0308-521X(93)90044-3

Sperling, L., Ashby, J. A., Smith, M. E., Weltzien, E., \& Mc Guire, S. (2001). Plant breeding approaches and results. Euphytica, 122(3), 439-450. http://dx.doi.org/10.1023/A:1017505323730

Trenbath, B. R. (1999). Multispecies cropping systems in India. Predictions of their productivity, stability, resilience and ecological sustainability. Agroforesty Systems, 45, 81-107. http://dx.doi.org/10.1023/A:1006285319817

Tripp, R. (2001). Seed provision and agricultural development. The institutions of rural change (p. 174). Londres, Oxford, Heinemann, Portmouth, James Surrey.

Trouche, G., Chantereau, J., \& Zongo, J. -D. (1998). Variétés traditionnelles et variétés améliorées de sorgho dans les régions sahéliennes. In L. Bacci \& et F-N. Reyniers (Eds.). Le futur des céréales photopériodiques pour une production durable en Afrique tropicale semi-aride, pp. 197-208.

Vaksmann, M., Kouressy, M., Chantereau, J., Bazile, D., Sagnard, F., Touré, A., \& Danté A. (2008). Utilisation de la diversité génétique des sorghos locaux du Mali. Cahiers Agricultures, 17(2), 140-145. http://dx.doi.org/10.1684/agr.2008.0190

Vaksmann, M., Traoré, S. B., Niangado, O. (1996). Le photopériodisme des sorghos africains. Agriculture et Développement, 9, 13-18.

Weltzien, E., Kanouté, M., Touré, A., Rattunde, F., Diallo, A., Sissoko, I., \& Siart, S. (2008). Sélection 
participative des variétés de sorgho à l'aide d'essais multilocaux dans deux zones cibles. Cahiers Agricultures, 17(2), 134-139. http://dx.doi.org/10.1684/agr.2008.0192

Wood, D., \& Lenné, J. M. (1997). The conservation of agrobiodiversity on-farm: questioning the emerging paradigm. Biodiversity and Conservation, 6, 109-129. http://dx.doi.org/10.1023/A:1018331800939

\section{Notes}

Note 1: AOPP: Association of Farmer Organisations; http://www.aopp-mali.org/

Note 2: IER: Institute of Rural Economy; http://www.ier.gouv.ml/

Note 3: CIRAD: Agricultural Research Centre for International Development; http://www.cirad.fr/

\section{Copyrights}

Copyright for this article is retained by the author(s), with first publication rights granted to the journal.

This is an open-access article distributed under the terms and conditions of the Creative Commons Attribution license (http://creativecommons.org/licenses/by/3.0/). 